マイククロデンシトメータ等を用い测定を試みた。

測定の結果, 患者頭部推定被曝線量約 $1.6 \mathrm{R}$ 強のうち, 画像構成に関与しない.つまりスキャンスライス領域外 への散乱線による被曝が，その中心部で約70\%，周边部 で約60\%も占められているととが判明した。

\section{4. $\mathrm{GE}$ 社製 $\mathrm{CT} / \mathrm{T}$ における腰椎スキャンの補助具の試} 作

\section{東北労災病院放射線科 \\ ○北島功次・本田茂・神田 真 高橋良行・鶴若 仁・高城政久}

〔目的】 CTはヘルニアの診断に有用になり，ヘルニ アは腰仙椎間に多く，その椎間板スキャンを行うのに骨 盤高位でスキャンしなければならない，その補助具を試 作した。

[方法] 腰仙椎間の椎間板傾斜角を男女各々 30 名の測 定を行い約 $28 ， 44$ となり骨盤高位傾斜 $13.5^{\circ}$ とガントり 一角 $15^{\circ}$ の合計 $28.5^{\circ}$ となり，13. $5^{\circ}$ を自動車用シャッ キで骨盤を上げるとととした。

〔結論】(1)腰仙椎間の椎間板スキャンが簡単にでき， (2)患者に苦痛を与えない，(3)スカウトビュで設定した通 りにスキャンできずれるととがない.

\section{CT 值の変動について}

新潟信楽園病院放身線科

○斎藤和男・小武内孝二・田中忠篤

CT 值が吸収係数の統計的変動で， ある幅をもってい ることに注目し，実際に均等物質に执いて CT 值がごの ように変動するのか調べてみた。

均等物質としてキャリブレーション，チェック用の水 ファントムを使用し，そのスライス画像について， ROI の面積や，測定位置を変えて装置の異常，キャリブレー ション前後, 管球取替前後等について CT 值を求めてみ た結果，かなり特異的な変化を示すととを確めた。

これらのととから，CT 值をさまざまの方法で測定， 記録することにより，装置の異常について，ある程度の 予測がつき，かつ，装置全体の精度管理の一端をむ果た せるものと判断した。

\section{CT (DELTA-2060) の被曝線量について}

弘前大学医学部附属病院放射線部

○不村 均·金 正宣・过 敏朗 須崎勝正・䓪西二郎・尾崎博一

石田 晃・沢田俊治・小山桂一 上田隆三

弘前大学医療技術短期大学部䛦療放射線技術学科
$\Delta 2060$ の被曝線量及び室内散乱線分布について報告し た. $\Delta$ はX線管球が左斜め上方より 1 回転し，さらに6 度オーバーラップして $1 \mathrm{scan}$ を終了するという方式の ため，その位置に高線量域が見られた。ACTA 200FSで は，右側下方であった。最高線量を測定すると，【では 頭部，腹部それぞれ $5.5 \mathrm{R} / 1 \mathrm{scan} 3.34 \mathrm{R} / 1$ scan で, ACTA ではむに比べて頭部では約半分, 腹部では，ほぼ 同等であった。

室内散乱線分布は，」ではベット右側下方の高線量域 の拡大が見られ, ACTA はベットの左右ほぼ同じ分布で あった．散乱線の分布の割合は，Uの方が, ACTA に比 ベて狭し範囲に分布していた。

\section{7. 当院における CT 装置の比較検討（第一報）} 岩手県立中央病院放射線科

○武蔵安徳・菊地訓久 藤井 仁・館・勉

〔目的】当院における CT 装置を，CATPHANを用 い比較検討したので報告する.

〔方法】CATPHANをCT-Scanし，得られた像をマ ルチフォーマットカメラで撮影し，その写真濃度をマイ クロデンシトメータで測定する.

〔結果〕 GRAYSCALE の濃度設定に関しては, EMI5005 の方が少し $\gamma$ が高い. Middle Contrast wedge に おいて window 幅を変えると，HE-CT の方が, EMI5005 の変化に比較して, 変化する割合が大きい.

その他の項目については，2装置間の差は少ない.

〔考案】 2 装置間で同じ level, 同じ window 幅で撮影 した. マルチフォーマット像に差を生じるのは，CRTの 調整にあると思われる。

\section{座長集約}

石田 晃 (弘前大学病院)

CT-II のグループは, 被曝に関するあの 2 題, 補助具 1 題, 装置の管理 1 題, 写真画像処理 1 題の計 5 題であ った. 33席屒尾氏と36席木村氏の被曝線量測定は，CT 装置が進歩しても被曝線量減少にはつがらないので，使 用する装置の線量測定は大切である。34席北島氏の補助 具は，腰椎 $\mathrm{V}$ 番と仙椎間の撮影には皆さん苦労している だけに有意義である。35席の斎藤氏の CT 装置定期点検 てついては，日常なおざりにされる面があり，努力のあ とがみられた. 37席の武蔵氏の CT 像を最終段階として 写真像にする時の問題点は直接 CT 診断にかかわるので 身近ながら重要である。乙の点については，色々質疑応 答が多かった. 5 氏の今後の研究を期待する。 